удк 159.955-021.412.1

Наталія Цьома

Сумський державний педагогічний

університет імені A. С. Макаренка

ORCID ID 0000-0001-5384-3405

DOI 10.24139/2312-5993/2019.07/317-324

\title{
ІНФОРМАЦІЙНА КОМПЕТЕНТНІСТЬ ЯК ОДИН В КОМПОНЕНТІВ ФОРМУВАННЯ ПРОФЕСІЙНО-ПЕДАГОГІЧНОЇ СКЛАДОВОЇ ПЕДАГОГА
}

Розглянуто всі групи компетентностей, які необхідно формувати для якісного освітнього процесу. Окреслено один із основних компонентів загальної профресійно-педагогічної комунікативної компетентності педагога - інформаційну компетентність. Виділено основні компоненти інформаційної компетентності: когнітивний, мотиваційно-ціннісний, професійно-діяльнісний, техніко-технологічний, комунікативний, рефлексивний. Визначено, що інформачійна компетентність реалізується під час проблемного навчання, у процесі використання мультимедійних технологій і застосування методу проектів, тобто здійснюється повноцінна високоефективна діяльність у розвиненому інформаційному суспільстві.

Ключові слова: інформачійне середовище, компетентність, інформатизація, інформаційна компетентність, педагог, учень, освітній процес, освіта.

Постановка проблеми. Проблема сучасного інформаційного суспільства на сьогоднішній день полягає не в інформації, а в можливості ії засвоювати й виробляти безпосередньо під впливом сучасних реалій, тобто у величезній кількості інформаційних потоків.

у даний час, у зв'язку із загальносвітовими тенденціями вдосконалення технологій і способів отримання, обробки й передачі інформації, відкриваються якісно нові можливості в сфері освіти. Розвиток інформаційних технологій, використання Інтернету, електронне навчання обумовлюють необхідність вивчення питань підготовки учнів із урахуванням пріоритетних напрямів інформатизації суспільства. Одним із основних вимог роботодавців стає якісна підготовка учнів для вирішення професійних завдань із використанням інформаційних технологій для успішного виконання трудових функцій.

Освітній процес, а особливо зміст і сутність діяльності педагога в сучасних умовах інформатизації освіти кардинально змінюється. З'являються нові методи й організаційні форми роботи, змінюються підходи до оцінювання діяльності учнів. У закладі освіти змінюється не тільки матеріальна база, яка оснащується новими засобами інформаційних технологій, якісні зміни відбуваються і в системі взаємодій у педагогічному колективі, націленому на розвиток особистості учнів, їх універсальних умінь. Грамотного і всебічно розвиненого учня може підготувати тільки педагог, який володіє сучасними педагогічними й інформаційними технологіями. 
Найважливішим фактором якісних змін інформаційного освітнього середовища стає здатність педагогів інтегрувати сучасні інформаційні та педагогічні технології для проведення цікавих занять, підвищення мотивації учнів до активної пізнавальної діяльності, навчання в співробітництві, дуальна форма навчання.

Аналіз актуальних досліджень. Необхідно відзначити, що в багатьох наукових розвідках досить глибоко розроблений загальний фундамент вивчення проблем компетентності. Це роботи І. А. Зимньої, Н. В. Кузьміної,
В. С. Леднева,
В. Я. Ляудіс,
Г. В. Мухаметзянова,
Дж. Равена,

В. Д. Шадрикова та ін.

Науковці Т. Г. Браже, В. М. Введенський, І. А. Зязюн, І. Ф. Кривонос, Н. В. Кузьміна, А. К. Маркова, Л. Я. Набока, В.В.Нестеров, І. П. Підласий, О. П. Ситник, М.І. Скрипник, Т. М. Сорокіна, К. М. Старченко, Л. М. Мітіна та ін. досліджували структуру та зміст професійної компетентності педагога.

Поняттю «інформаційна компетентність» приділяють увагу Н. В. Морзе, Е. Н. Гусинський, О. Б. Зайцева, А. В. Хуторський та ін.

Метою статті $€$ визначення інформаційної компетентності як структурного компонента професійно-педагогічної комунікативної компетентності педагога в сучасному освітньому просторі.

Методи дослідження. Для досягнення поставленої мети було використано комплекс взаємопов'язаних та взаємоузгоджених методів, а саме: теоретичний аналіз, синтез, узагальнення, порівняння, систематизація.

Виклад основного матеріалу. У сучасному освітньому процесі найбільш значущим стає продуктивна взаємодія педагога та учнів, що будується на взаєморозумінні. Потрібна така організація освітнього процесу, коли позиція учня з пасивного слухача переходить на позиції активного дослідника з метою спільного вивчення явищ і процесів у групах на основі ефективного використання сучасних інструментів роботи 3 інформацією. Система активної й ефективної взаємодії педагога та учня переходить у систему співробітництва, педагог виконує роль тьютора, мотиватора, а іноді ментора чи наставника.

Залученість учнів в освітній процес $є$ найбільш значущим чинником, що впливає на якість знань. В основі освітньої діяльності лежить уміння працювати з інформацією в різних її видах, універсальне вміння «читати тексти», тобто співвідносити тексти 3 дійсністю, інтерпретувати і структурувати їх, усвідомлювати, що $€$ зрозумілим, яка частина викликає питання, уточнення. Організація відповідних педагогічних умов дає можливість учням роздумувати над важливими питаннями і проблемами, вирішення яких не лежить на поверхні.

Однак, при роботі й пошуку інформації учні також повинні розробляти свої особисті фільтри, оцінюючи такі невід'ємні якості 
інформації, як об'єктивність, достовірність, повнота, точність, актуальність і корисність. Більш серйозної оцінки на відповідність критеріям якості інформації повинні піддаватися Інтернет ресурси. Учні активно використовують Інтернет у власних цілях, для них це і спілкування, і гра, і захоплення, і багато іншого.

Комп'ютер дає можливість легкого доступу до будь-якої інформації, ілюзію моментального отримання відповіді на різні питання. І, як результат, учні втрачають інтерес та бажання до власних відкриттів, залишається легкий доступний «серфінг» у мережі Інтернет. Відбувається конфлікт знань і інформації: учням все важче стає зосередитися на певній думці, проявити власну уяву, глибоке розуміння, рефлексію. Звідси небажання докладати інтелектуальні зусилля для вирішення питань і проблем, невміння сформулювати власні думки, організувати продуктивну взаємодію в реальних відносинах, $€$ тільки ковзання поверхнею. Як наслідок, процес навчання стає для учнів дуже важкою й незвичною працею, і педагогу все важче шукати підходи, щоб залучити їх до освітнього процесу (Громыко, 2002, с. 180).

Європейські країни сьогодні розпочали ґрунтовну дискусію навколо того, як озброїти педагогів необхідними вміннями та знаннями для забезпечення гармонійної взаємодії учнів із інформаційним суспільством, що швидко розвивається. Саме тому важливим є усвідомлення поняття компетентності в педагогічній науці та практиці, суспільстві, що базується на знаннях. Потрібно визначити, які саме компетентності необхідно формувати для якісного освітнього процесу. Науковці виділяють такі групи компетентностей:

1. Соціальна компетентність (social competence) - здатність брати відповідальність, співробітництво, ініціатива, активна участь, динамічні знання. Це поняття включає також відкритість до світу та відповідальність за навколишнє середовище, уміння працювати в команді (що включає традиційне поняття робочої етики).

2. Комунікативна - уміння спілкуватися усно та письмово, рідною та іноземними мовами.

3. Полікультурна - не тільки оволодіння досягненнями культури, а розуміння та повага до людей інших національностей, релігій, культур, мов, рас, політичних уподобань та соціального становища.

4. Інформаційна - уміння добувати, осмислювати, опрацьовувати та використовувати інформацію з різних джерел.

5. Саморозвитку та самоосвіти - мати потребу й готовність постійно навчатися впродовж усього життя.

6. Продуктивної творчої діяльності (Редун).

Одним із основних компонентів загальної професійно-педагогічної комунікативної компетентності педагога, яка характеризується вмінням працювати з інформацією, є інформаційна компетентність. 
Інформаційна компетентність - це вміння переосмислювати інфрормацію, розв'язувати інформаційно-пошукові задачі, використовуючи бібліотечні та електронні інформачійно-пошукові системи, тобто здійснювати інформаційну діяльність із використанням як традиційних, так і нових технологій (Аханян та Кизик, 2007).

До значущих ознак інформаційної компетентності (за М. Головань) належать: знання інформаційних технологій як предмета; використання комп'ютера як необхідного технічного засобу; сукупність знань, умінь та навичок пошуку, аналіз інформаційних даних; ціннісне відношення до інформаційної діяльності; наявність актуальної освітньої чи професійної задачі, у якій актуалізується та формується інформаційна компетентність (Головань, 2008).

у якості основних виділяються такі компоненти інформаційної компетентності:

- когнітивний: відображає процеси переробки інформації на основі таких актів, як аналіз інформації, що надходить, формалізація, порівняння, узагальнення, синтез із наявними базами знань, розробка варіантів використання інформації та прогнозування наслідків реалізації вирішення проблемної ситуації, генерування та прогнозування використання нової інформації та взаємодія ії̈ з наявними базами знань, організація зберігання та відновлення інформації в довгостроковій пам'яті;

- мотиваційно-ціннісний, що полягає у створенні умов, які сприяють входженню педагога в світ цінностей, які надають допомогу при виборі важливих ціннісних орієнтацій; характеризує ступінь мотиваційних спонукань педагога, що впливають на ставлення до роботи і до життя в цілому;

- професійно-діяльнісний, який визначається як здатність застосовувати інформацію, володіння сучасними методами і способами пошуку, збору освітньої інформації, уміння знаходити інформацію з різних джерел, уміння систематизувати й узагальнювати інформацію, уміння використовувати отриману інформацію для професійно-педагогічної діяльності;

- техніко-технологічний, що відображає розуміння принципів роботи, можливостей і обмежень технічних пристроїв, призначених для автоматизованого пошуку та обробки інформації; знання відмінностей автоматизованого та автоматичного виконання інформаційних процесів; уміння класифікувати задачі за типами з подальшим рішенням і вибором певного технічного засобу залежно від його основних характеристик; знання особливостей засобів інформаційних технологій з пошуку, переробки та зберігання інформації; технологічні навички та вміння роботи з інформаційними потоками (зокрема, за допомогою засобів інформаційних технологій);

- комунікативний - відображає знання, розуміння, застосування природних і формальних мов, технічних засобів комунікацій для передачі інформації від однієї людини до іншої за допомогою різноманітних форм і способів спілкування (вербальних і невербальних); 
- рефлексивний - усвідомлення власного рівня саморегуляції педагога, при якому життєва функція самосвідомості полягає в самоврядуванні власною поведінкою, а також у розширенні самосвідомості, самореалізації в педагогічній сфері (Шелер, 1994).

На наш погляд, тільки комплексне застосування представлених елементів дозволить не тільки формувати, але й розвивати інформаційну компетентність педагогів.

Сьогодні інформатизація освіти відбувається за допомогою цілого комплексу заходів, пов'язаних із перетворенням педагогічних процесів на основі впровадження в навчання інформаційних технологій. Використання в навчальному процесі сучасних технічних пристроїв та інформаційних технологій призводить до нового розуміння дидактичного процесу, його аналізу, установлення нових принципів навчання. Так, принцип доступності (традиційне навчання) реалізується з урахуванням індивідуальних та вікових особливостей учнів, (комп'ютерне навчання) - «відбувається перехід від принципу загальної доступності до принципу індивідуальної доступності» (Верлань та ін., 1996, с. 128).

Найефективніше інформаційна компетентність реалізується під час проблемного навчання, у процесі використання мультимедійних технологій і застосування методу проектів. Під час даних форм навчання формуються навички інформаційної компетентності, тобто здійснюється повноцінна високоефективна діяльність у розвиненому інформаційному суспільстві. Крім пошуку і роботи з якісною інформацією, що відповідає всім критеріям, учень у сучасному суспільстві повинен вчитися нести відповідальність за використання і створення неякісної інформації, усвідомлення наслідків такої інформації. Це означає, що повинна вироблятися так звана комунікативна відповідальність або комунікативна дисципліна.

Дана навичка починає відігравати важливу роль у житті кожного індивіда вже на ранніх етапах освіти при пошуку базових відповідей на запитання. Уміння визначати якісну інформацію підвищує можливість самоосвіти учнів. При розвитку методик роботи з джерелами автоматично вирішується проблема неефективної трати часу. Так, учні вчаться оцінювати джерела, розвивають свої інформаційні можливості.

Важливо, щоб технології роботи з інформацією, Інтернет стали для учнів засобами поглиблення інтересу до теоретичного мислення й сутнісним, фундаментальним знанням, щоб сучасні інструменти і форми роботи з інформацією послужили їм основою для формування відносин, у яких формуються професійні цінності.

Формування вмінь, зокрема інформаційних, буде тим ефективніше, чим глибше особистість педагога оволодіє інформаційними знаннями й відповідними навичками - автоматизованими усвідомленими діями, що сприяють швидкому та точному відображенню ситуацій на уроках. 


\section{Висновки та перспективи подальших наукових розвідок.} Підсумовуючи викладене, можна зауважити, що важливим компонентом формування професійно-педагогічної комунікативної компетентності особистості $\epsilon$ інформаційна компетентність. Вона $\epsilon$ однією з основних напрямів процесу інформатизації в освіті й потребою сучасного суспільства. Разом із тим, необхідно відзначити, що нині в теорії і практиці професійної освіти назріла необхідність подальших пошуків найбільш ефективних способів і засобів формування інформаційно-комунікативної компетенції педагогів та учнів.

\section{ЛITEPATУPA}

Carrington, Allan. University of Adelaide. URL: https://designingoutcomes.com/.

Аханян, А. А., Кизик, О. А. (2007). Зарубежный опыт развития информационной компетентности учащихся. Электронный научно-педагогический журнал. URL: http://www.emissia.org/offline/2007/1220.htm (Akhanian, A. A, \& Kizik, O. A. (2007). Foreign experience of students' information competence development. Electronic scientific-pedagogical journal. Retrieved from: http://www.emissia.org/offline/2007/1220.htm).

Верлань, А. Ф., Тверезовська, Л. О., Федорчук, В. А. (1996). Інформаційні технології в сучасній школі. Кам'янець-Подільський: Кам'янець-Подільський держ. пед. інститут (Verlan, A. F., Tverezovska, L. O., \& Fedorchuk, V. A. (1996). Information technology in modern school. Kamianets-Podilsky: Kamianets-Podilskyi state ped. institute).

Волкова, Н. П. (2006). Професійно-педагогічна комунікація. Київ: Академія (Volkova, N. P. (2006). Professional-pedagogical communication. Kyiv: Academy).

Головань, М. С. (2008). Розвиток інформатичної компетентності студентів як педагогічної системи. Педагогічні науки, 88-96 (Golovan, M. S. (2008). Development of computer competence of students as a pedagogical system. Pedagogical sciences, 88-96).

Громыко, Н. В. (2002). Интернет и постмодернизм - их значение для современного образования. Вопросы философии , 2, 175-180 (Gromyko, N. V. (2002). The Internet and postmodernism are their significance for modern education. Philosophy Issues, 2 , 175-180).

Исмагилова, Ф. С. (2000). К проблеме психологического анализа профессионального опыта. Вестник Московского университета. Сер. 14: Психология, 2, 16-27 (Ismagilova, F. S. (2000). On the problem of psychological analysis of professional experience. Bulletin of M oscow University. Sir 14: Psychology, 2, 16-27).

Когут, І. В. (2012). Теоретичні основи розвитку професійно-педагогічної комунікації в умовах сучасного інформаційного суспільства. Procedeengs of VIII International scientific-practical conference "Science: theory and practice - 2012", 5: Pedagogical sciences, pp. 68-73 (Kohut, I. V. (2012). Theoretical bases of development of professional-pedagogical communication in the conditions of modern information society. Procedeengs of VIII International scientific-practical conference "Science: theory and practice - 2012", 5: Pedagogical sciences, pp. 68-73).

Куницына, В. Н., Карпова, Н. В., Погольша, В. М. (2001). Межличностное общение. СПб. (Kunitsyna, V. N., Karpova, N. V., \& Poholsha, V. M. (2001). Interpersonal communication. SPb.). 
Микешина, Л. А. (2005). Философрия науки. М.: Флинта (Mikeshyna, L. А. (2005). Philosophy of science. M .: Flinta).

Орлова, Э. А. (2004). Культурная (социальная) антропология. М.: Академический проект (Orlova, E. A. (2004). Cultural (social) anthropology. М.: Academic project).

Основные результаты Международного исследования PISA-2015. URL: http:// centeroko.ru. (The main results of International assessment PISA-2015. Retrieved from: http:// centeroko.ru).I

Редун, О. В. Роль самостійної роботи студентів у підвищенні мотивації вивчення іноземної мови. URL: http://archive.nbuv.gov.ua/portal/Soc_Gum/M enedzhment/ 2010_13/redun.htm. (Redun, 0. V. The role of independent work of students in increasing the motivation of studying a foreign language. Retrieved from: http://archive.nbuv.gov.ua/portal/Soc_Gum/M enedzhment/ 2010_13 / redun.htm).

Рудакова, Д. Т. (2013). Информация и культура как векторы развития современной образовательной среды школы. Развитие общеобразовательного курса информатики в контексте современной информационной цивилизации, 59-68. Карачаевск: КЧГУ (Rudakova, D. T. (2013). Information and culture as vectors of development of the modern educational environment of the school. Development of the general course of computer science in the context of modern information civilization, 59-68. Karachaievsk).

Структура ИКТ-компетентности учителей. Рекомендации ЮНЕСКО: Опубликовано в 2011 г. Организацией Объединенных Наций по вопросам образования, науки и культуры (ЮHECKO).

URL: http://iite.unesco.org/pics/publications/ru/files/3214694.pdf (The structure of ICT competence of teachers. UNESCO recommendations: Published in 2011 by the United Nations Educational, Scientific and Cultural Organization (UNESCO). Retrieved from: http://iite.unesco.org/pics/publications/ru/files/3214694.pdf).

Шелер, М. (1994). Философрское мировоззрение. М.: Гнозис (Scheler, М. (1994). Philosophical Worldview. M.: Gnosis).

\section{PEЗЮME}

Цёма Наталия. Информационная компетентность как один из компонентов формирования профессионально-педагогической составляющей педагога.

Рассмотрены все группы компетентностей, которые необходимо формировать для качественного образовательного прочесса. Определен один из основных компонентов общей профессионально-педагогической коммуникативной компетентности педагога - информационная компетентность. Выделены основные компоненты информационной компетентности: когнитивный, мотивационно-ценностный, профессионально-деятельностный, техникотехнологический, коммуникативный, рефлексивный. Определено, что информационная компетентность реализуется во время проблемного обучения, при использовании мультимедийных технологий и применении метода проектов, то есть осуществляется полноценная высокоэфррективная деятельность в развитом информационном обществе.

Ключевые слова: информационная среда, компетентность, информатизация, информационная компетентность, педагог, ученик, образовательный прочесс, образование. 


\section{SUM MARY}

Tsoma Natalia. Information competence as one of the constituents of forming a professional-pedagogical component of a teacher.

The most important factor in the qualitative changes in the information educational environment is the ability of teachers to integrate modern information and pedagogical technologies to conduct interesting classes, increase students' motivation for active cognitive activity, study in collaboration, and a dual form of training.

The basis of educational activity is the ability to work with information in its various forms, the universal ability to "read texts", that is, to correlate texts with reality, interpret and structure them, to realize that it is clear which part raises questions, clarifications.

It is necessary to determine exactly which competences must be formed for a highquality educational process. Scientists distinguish such groups of qualities: social, communicative, multicultural, informational competence, self-development and selfeducation, productive creative activity.

One of the main components of the general professional-pedagogical communicative competence of a teacher, characterized by the ability to work with information, is information competence.

Information competence is the ability to rethink information, solve information retrieval tasks using library and electronic information retrieval systems, that is, carry out information activities using both traditional and new technologies.

The main components of information competence are distinguished: cognitive, motivational-value, professional-active, technical-technological, communicative, reflexive. In our opinion, only the integrated application of the presented elements will allow not only to form, but also to develop the information competence of teachers.

Effectively, information competence is realized in case of problem-based learning, using multimedia technologies and applying the project method. During these forms of training, information competence skills are formed, that is, a full-fledged highly effective activity is carried out in a developed information society.

The technology of working with information, the Internet has become for students a means of deepening interest in theoretical thinking and essential, fundamental knowledge, so that modern tools and forms of working with information serve as the basis for the formation of values.

Key words information environment, competence, informatization, information competence, teacher, student, educational process, education.

удк 378.093.2:[61:005.336.2]:53

Людмила Яковишена

Вінницький державний педагогічний університет імені Михайла Коцюбинського ORCID ID 0000-0001-9197-8538 DOI 10.24139/2312-5993/2019.07/324-336

\section{ІНТЕГРАЦІЯ ФУНДАМЕНТАЛЬНОЇ ТА ФАХОВОЇ ПІДГОТОВКИ МАЙБУТНІХ МОЛОДШИХ МЕДИЧНИХ СПЕЦІАЛІСТІВ У ПРОЦЕСІ ВИВЧЕННЯ ПРИРОДНИЧО-НАУКОВИХ ДИСЦИПЛІН}

Стаття присвячена проблемі інтеграції фундаментальної та фрахової підготовки майбутніх молодших медичних спеціалістів у процесі вивчення природничо-наукових дисциплін. Розглянуто комплекс навчально-методичних засобів, 